\title{
Exploring the Dimensions of Pro-environmental Practices in Construction Firms
}

\author{
Nor'Aini Yusof, Mohammad Iranmanesh, and Aminu Garba Waziri
}

\begin{abstract}
The potential of the construction industry to contribute toward environmental sustainability placed increased pressure on the need for pro-environmental practices (PEP) in the sector. Research has indicated that environmental quality is associated with human behavior; thus, PEP in construction firms is imperative. Studies on the PEP of construction firms are limited. This study aims to explore the PEP dimensions in construction firms, specifically among architectural, engineering, and contracting (AEC) firms. Questionnaires were distributed to AEC firms in Penang, Malaysia; 375 useable responses were obtained. After data analysis, four factors emerged as the PEP dimensions of firms. These factors are energy efficiency, paper recycling, office waste recycling, and involvement in pro-environmental efforts. The findings provide valuable understanding on PEP that is available in construction firms.
\end{abstract}

Index Terms - Construction firms, construction industry, Malaysia, pro-environmental practices.

\section{INTRODUCTION}

According to the International Energy Statistics [1], Malaysia is $28^{\text {th }}$ in the global carbon dioxide emission rankings. In reaction to this environmental issue, the Malaysian prime minister pledged during the 2009 United Nations summit on climate change to reduce the greenhouse gas emissions of Malaysia by $40 \%$ by 2020 [2]. As part of the commitment, the government, through the Ministry of Environment and Natural Resources, recently launched the MyCarbon program or the National Corporate Green House Gas Reporting Programme for Malaysia [2]. Leading institutions such as the Construction Industry Development Board (CIDB) identified sustainability and environment as the prime focus of research and development [3], thus prompting the launch of Bursa Malaysia's Business Sustainability Programme for corporate Malaysia, which aims to assist publicly listed companies in integrating environmental, social, and governance issues in their everyday business operations. In the early part of 2010, the Prime Minister announced, under the fifth strategic thrust of the $10^{\text {th }}$ Malaysia Plan, that the government would promote an environmentally friendly agenda in the construction industry by introducing a green rating system, with the government

Manuscript received December 5, 2014; revised May 4, 2015. This work was supported by the Malaysian government through Exploratory Research Grant Scheme (ERGS) grant number 203/PPBGN/6730132.

Nor'Aini Yusof and Aminu Garba Waziri are with School of Housing, Building and Planning, Universiti Sains, Malaysia (e-mail: ynoraini@usm.my, agwziri@yahoo.com).

Mohammad Iranmanesh is with School of Management, Universiti Sains, Malaysia (e-mail: iranmanesh.mohammad@gmail.com). leading the adoption of green building standards in new public buildings [3]. Therefore, the basic and fundamental principles of a construction product are no longer sufficient. The move resulted in awareness among key players in the construction industry on the potential of pro-environmental practices (PEP) to minimize the negative effect of construction activities on the environment [4].

The key players in construction industry include architects, engineers, and contractors [5]. Architects and engineers are consultants who provide design and project management services to clients [5], whereas contractors are primarily involved during the construction phase and carry out the actual construction work [6]. Presently, literature on the environmental practices of construction practitioners is scarce. Studies that do exist on environmental sustainability in construction sector do not focus on the type of PEP exists among AEC firms. The studies by Zainul Abidin [3] and Zainul Abidin and Yusof [4] for example, focused on the implementation of sustainable construction including the drivers and challenges of such implementation in developers organizations. There seems to be dearth of evidence emerging from the literature on PEP at AEC firms level. According to Berthou [7], how PEP is integrated into the daily routine of an individual-including the practices of firms should be examined. The construction sector has been slow in responding to PEP requirements compared with other sectors, such as manufacturing [3]. This finding brings us to the main question of the present study: What type of PEP exists among practitioner firms in the construction industry, specifically architectural, engineering, and contracting (AEC) firms?

Theoretically, the findings contribute to knowledge by explaining the holistic firm-level behavior of key players in the construction industry toward PEP. These findings are also useful in helping policy makers and managers of construction firms explore environmentally friendly behaviors in the construction sector. The findings provide specific policy recommendations for stimulating PEP among the relevant professional bodies in the the construction industry. Moreover, the findings serve as a guide to augment the pro-environmental initiatives of the industry and facilitate the achievement of the fifth strategic thrust in the $10^{\text {th }}$ Malaysia Plan and the broader goal of sustainability.

\section{ENVIRONMENTAL PRACTICES}

Pro-environmental practices refers to practices that harm the environment as little as possible, or those practices that benefit the environment [8]. Pro-environmental practices also relates to environmental management strategies that involve various practices aimed at minimizing the negative 
environmental effects of firm products and services [9]. At the organizational level, Garces-Ayerbe et al. [10] defined PEP as the embodiment of environmental proactivity that goes beyond regulatory compliance. These practices are evident in terms of energy conservation at one's working environment, as well as in waste management and participation in pro-environmental activities. Pro-environmental practices implies practices in terms of reducing energy consumption, reusing, and recycling [11]. In addition, scholars such as Alpízar and Gsottbauer [12] describe PEP as the readiness to cooperate and contribute to public environmental comfort. In the construction sector, PEP requires changing from conventional practices to approaches that reduce the negative effects of construction activities on the environment [4].

Firm PEP is driven by individuals who operate within the organization, particularly at the managerial level. Certain firms are adamant in adopting environmental practices regardless of the potential to increase profit or legal requirements [13]. By contrast, other firms are willing to adopt PEP but are faced with constraints that hinder the adoption of pro-environmental behaviors [14]. For example, a firm may still intend to maintain its existing manner of doing business, and may not be prepared to sacrifice convenience, accept lower performance levels, or face competency realignment. These constraints may hamper the implementation of PEP. In addition, practitioners strive to enhance the environmental image of their firms for competitive advantages. Alpízar and Gsottbauer [12] argue that reputational concern is positively associated with PEP. Construction practitioners prefer to be identified with government programs that inform of participation in environmental policies. Similarly, individuals who feel a deep emotional connection to nature and who incorporate nature in their self-concept are likely to become environmentalists. They are relatively more apprehensive about the consequences of environmental problems on themselves, on other people, and their working environment [15].

\section{MeTHODOLOGY}

A quantitative survey with a structured questionnaire was used in this study. The population of this study includes key practitioners in the construction industry, particularly in architectural, engineering, and contracting firms. The questionnaire was administered face-to-face. The state of Penang was selected as a case study because it is one of the states with high rate of construction activities. One thousand questionnaires were distributed, and 384 responses were received. Out of the 384 responses, 4 were partially completed and 5 were discarded in data cleaning, thereby leaving a total of 375 responses, or a $37.5 \%$ response rate.

In addition to the basic information on firms, the personal information on respondents was also obtained. The questionnaire consists of 17 items of PEP (Appendix), which were measured using five-point Likert scales anchored by "never" and "always." To ensure content validity, the items were adapted from SHRM [16] and OEA [17]. The items were submitted to factor analysis to identify PEP dimensions.

\section{REsUlts}

\section{A. Sample}

The final sample consisted of $176(46.9 \%)$ engineers, 137 (36.5\%) professional engineers, $33(8.8 \%)$ directors, and 29 $(7.7 \%)$ other professionals. Employees dominated the survey (90.4\%). Majority of the companies have been operating for more than 10 years in Malaysia $(68.6 \%)$ and are owned by foreigners $(72.5 \%)$. Majority of the respondents have less than 10 years of working experience in the construction industry $(62.7 \%)$. The data also indicated that $75.7 \%$ of the firms have less than 50 employees.

\section{B. Pro-environmental Practices of Practitioner Firms}

Prior to factor analysis, the items were submitted to Kaiser-Meyer-Olkin (KMO) measure of sampling adequacy and Bartlett's test. The results are presented in Table I. The KMO value for this study is 0.880 , and the test of sphericity value is significant $(p<0.01)$. The results allowed us to proceed with factor analysis.

Varimax rotation was used to explore dimensionality in the data set. Four components emerged as dimensions of PEP and explain $71.25 \%$ of the total variance. The Cronbach's alpha of each component exceeded the recommended value of 0.7 , as set by Pallant [18]. Office waste recycling explains the highest percentage of the total variance $(23.81 \%)$. This dimension is exemplified in recycling cardboard, magazines, brochures, toner and ink jet printer cartridges, glass containers, and aluminum cans.

Involvement in pro-environmental efforts is the dimension with the second highest percentage of the total variance $(19.87 \%)$. It is manifested by firms that encourage their employees to use public transport, carpool, partner with pro-environment suppliers, sponsor environmentally friendly events in the community, and use products that are harmless to the environment.

TABLE I: FACTOR ANALYSIS-ROTATED COMPONENT MATRIX

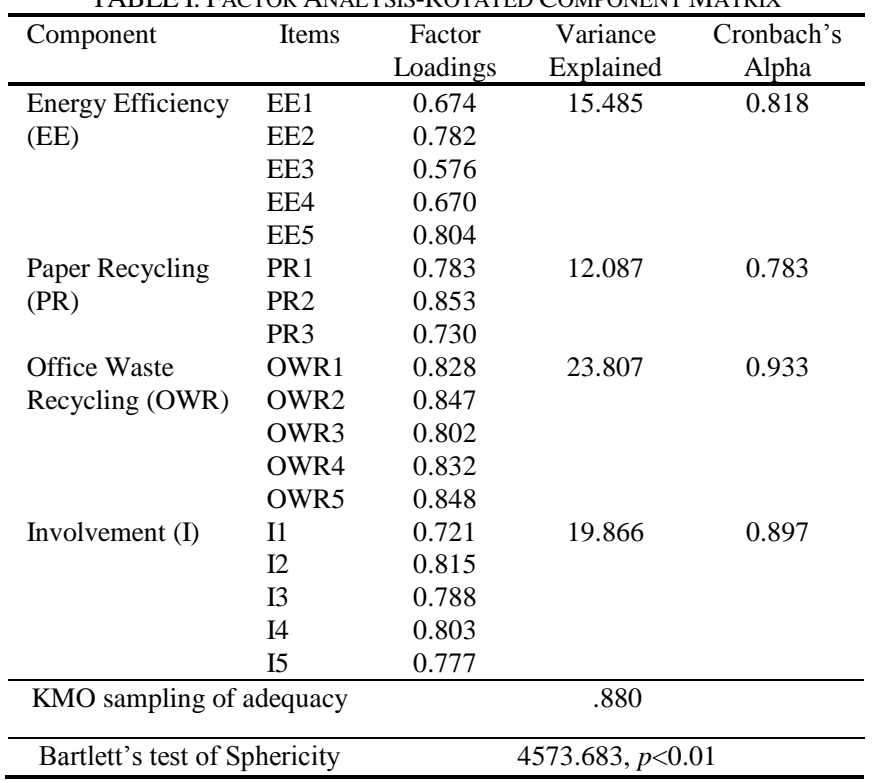

The dimension with the third highest percentage of total variance is energy efficiency $(15.49 \%)$. It is related to using sensors and energy-saving light bulbs, as well as powering off computers when not in use, to save energy. 
Paper recycling is the last dimension of construction firms' PEP (12.09\%). It entails the use of recycled paper and recycling of computer and office papers.

The Cronbach's alphas of all of the components are above 0.7 and thus support the internal cohesiveness of the items that form each component [19].

We performed a descriptive analysis of items and computed the mean scores for eco-environmental practices (Table II). The results indicate that paper recycling exhibits the highest mean value (2.66), followed by energy efficiency (2.14), office waste recycling (2.10), and activity involvement (1.66). Paired-sample $t$ test was conducted to determine whether a significant difference exists between mean scores. The result reveals a significant difference among the mean values of all eco-environmental practices, except for energy efficiency and office waste recycling. The result suggests that paper recycling is the dominant eco-environmental practice among AEC firms in Malaysia. However, these firms demonstrate a weak tendency toward involvement.

TABLE II: MEAN SCORES FOR PRO-ENVIRONMENTAL PRACTICES

\begin{tabular}{lll}
\hline & Mean & Std. Deviation \\
\hline Energy Efficiency (EE) & 2.14 & 0.97 \\
\hline EE1 & 2.02 & 1.18 \\
EE2 & 2.41 & 1.18 \\
EE3 & 2.16 & 1.36 \\
EE4 & 1.98 & 1.41 \\
EE5 & 2.14 & 1.25 \\
\hline Paper Recycling (PR) & 2.66 & 0.86 \\
\hline PR1 & 2.58 & 1.05 \\
PR2 & 2.77 & 1.02 \\
PR3 & 2.61 & 1.02 \\
\hline Office Waste Recycling & 2.10 & 1.00 \\
(OWR) & & \\
\hline OWR1 & 2.14 & 1.24 \\
OWR2 & 2.10 & 1.24 \\
OWR3 & 1.88 & 1.21 \\
OWR4 & 1.81 & 1.24 \\
OWR5 & 1.83 & 1.23 \\
\hline Involvement (I) & 1.66 & 1.02 \\
\hline I1 & 1.53 & 1.35 \\
I2 & 1.79 & 1.14 \\
I3 & 1.78 & 1.17 \\
I4 & 1.44 & 1.28 \\
I5 & 1.77 & 1.13 \\
\hline
\end{tabular}

\section{DISCUSSION}

This study investigates the extent of PEP among construction firm practitioners in Malaysia. The present study categorized the PEP of AEC firms into four types of practices, namely energy efficiency, paper recycling, office waste recycling, and firm involvement in environmentally friendly efforts.

The results indicate that paper recycling is the dominant pro-environmental practice among AEC firms in Malaysia. Recycling is the part of waste management that-according to scholars such as Barr [20] emphasizes values, the environment, situational factors, and psychological factors. Recycling practices can help to prevent or minimize wastage and thus contribute to the overall aim of environmental sustainability [14].

AEC firms in Malaysia also manifest the satisfactory practice of energy efficiency and office waste recycling. Energy efficiency is related to the use of environmentally friendly technology, which is consistent with the findings of Irimiya et al. [21], who stated that a remarkable percentage of energy saving can be accomplished using appropriate and available technologies.

The involvement of firms in environmentally friendly efforts entails participation in activities, such as partnering with environmentally friendly suppliers and using environmentally responsible products. AEC firms in Malaysia rarely participate in these types of activities despite their awareness of the need to protect the environment, as mentioned by Zainul Abidin [3], and despite pressure from the government [2]. This finding provides insufficient evidence to support the work of Garces-Ayerbe et al. [10] and Alpízar and Gsottbauer [12] on participation in environmentally friendly efforts.

\section{CONCLUSION}

Theoretically, the study contributes to existing knowledge by providing enhanced understanding of the PEP that exists in AEC firms. The findings are beneficial to construction industry stakeholders because the results provide information about PEP level; such information may help practitioners to give increased consideration to practices that have received less attention from AEC firms - in our case AEC firms involvement with environmentally friendly suppliers or companies and use of environmentally responsible products. Identifying environmentally friendly suppliers and encouranging employees to use environmentally responsible products are among the initial steps that can be taken by AEC firms. Having an environmental preferable purchasing policy is another measure that can be taken to increase AEC firms involvement in PEP. This study also supplements the existing literature on PEP in the construction sector by providing the dimensions of PEP at the organizational level which consists of Paper Recycling, Energy Efficiency, Office waste Recycling and Involvement.

Future research could extend the study by investigating ways to increase firms involvement in PEP efforts and the influence of AEC's PEP on the environmental performance of construction projects. Identifying factors that can increase AEC firms involvement in PEP efforts and the most influential PEP to encourage similar pro-environmental behavior in construction projects will add value to the existing knowledge.

\section{APPENDIX}

\section{Questionnaire Items}

\section{1) Energy efficiency}

- My firm uses sensors or timers to save electricity in intermittently used areas.

- My firm has energy-saving light bulbs in all areas.

- My firm encourages employee to power off the computers after a few minutes of inactivity.

- My firm uses energy-efficient bulbs for desk lamps.

- My firm uses energy-efficient lighting system and equipment.

\section{2) Paper recycling}


- My firm recycles paper.

- My firm uses recycled paper.

- My firm recycles computer and office papers.

3) Office waste recycling

- My firm recycles cardboard.

- My firm recycles magazines and brochures.

- My firm recycles toner and ink jet printer cartridges.

- My firm recycles glass containers.

- My firm recycles aluminum cans. 4) Involvement

- My firm promotes walking, biking, and taking public transport.

- My firm partners with environment-friendly suppliers/companies.

- My firm participates in or sponsors projects/events in the community to improve the environment.

- My firm encourages/promotes/provides carpooling for employees.

- My firm uses environmentally responsible products throughout the property/project.

\section{ACKNOWLEDGMENT}

The authors would like to thank all firms, which have participated in the survey, for the time and efforts they invested. In addition, special thank to all fieldworkers for their contribution in carrying out the survey.

\section{REFERENCES}

[1] International Energy Statistics, Key World Energy Statistics. (2011). Paris: IEA. [Online]. Available: http://www.iea.org/publications/freepublications/publication/key_wor ld_energy_stats-1.pdf

[2] MyCarbon. (October 2012). National Corporate GHG Reporting Programme for Malaysia. [Online]. Available: http://www.mpma.org.my/Documents/MYCarbon\%20booklet_print \%20format.pdf

[3] N. Z. Abidin, "Investigating the awareness and application of sustainable construction concept by Malaysian developers," Habitat International, vol. 34, pp. 421-426, 2010.

[4] N. Z. Abidin, N. A. Yusof, and A. A. E. Othman, "Enablers and challenges of a sustainable housing industry in Malaysia," Construction Innovation, vol. 13, no. 1, pp. 10-25, 2013.

[5] L. Shi, K. Ye, W. Lu, and X. Hu, "Improving the competence of construction management consultants to underpin sustainable construction in China," Habitat International, vol. 41, pp. 236-242, 2014.

[6] Y. C. Yong and N. E. Mustaffa, "Critical success factors for Malaysian construction projects: an empirical assessment," Construction Management and Economics, vol. 31, pp. 959-978, 2013.

[7] S. Berthoû, "The everyday challenges of pro-environmental Practices," The Journal of Transdisciplinary Environmental Studies, vol. 12, pp. 53-68, 2013

[8] L. Steg and C. Vlek, "Encouraging pro-environmental behaviour: An integrative review and research agenda," Journal of environmental Psychology, vol. 29, pp. 309-317, 2009.

[9] M. E. Dief and X. Font, "Determinants of environmental management in the Red Sea Hotels: personal and organizational values and contextual variables," Journal of Hospitality \& Tourism Research, vol. 36, no. 1, pp. 115-137, 2012.

[10] C. Garcés-Ayerbe, P. Rivera-Torres, and J. Murillo-Luna, "Stakeholder pressure and environmental proactivity: Moderating effect of competitive advantage expectations," Management Decision, vol. 50, no. 2, pp. 189-206, 2012.

[11] A. Ebreo and J. Vinning, "Conservation-wise consumers: Recycling household shopping as ecological behaviour," Journal of Environmental Systems, vol. 23, pp. 109-131, 1994.
[12] F. Alpízar and E. Gsottbauer, "Reputation and household recycling practices: Field experiments in Costa Rica," Environment for Development, Discussion Paper Series, EFD, DP13-13, 2013.

[13] D. L. Gadenne, J. Kennedy, and C. McKeiver, "An Empirical Study of Environmental Awareness and Practices in SMEs," Journal of Business Ethics, vol. 84, pp. 45-63, 2009.

[14] M. Gangolells, M. Casals, S. Gasso, N. Forcada, X. Roca, and A. Fuertes, "Assessing concerns of interested parties when predicting the significance of environmental impacts related to the construction process of residential buildings," Building and Environment, vol. 46, pp. 1023-1037, 2011.

[15] P. W. Schultz, "The structure of environmental concern: Concern for self, other people, and the biosphere," Journal of Environmental Psychology, vol. 21, pp. 327-339, 2001.

[16] SHRM, Green Workplace. (2008). [Online]. Available: http://www.shrm.org/research/surveyfindings/articles/documents/shr m\%20green\%20workplace\%20survey\%20brief.pdf

[17] OEA. The University of Queensland Green Office Program. (2010). [Online]. Available: http://uq.edu.au/sustainability/docs/greenoffice/Grn_AssmntFrm.pdf

[18] J. Pallant, SPSS Survival Manual: A Step by Step Guide to Data Analysis Using SPSS, 4th ed., Crows Nest: Allen \& Unwin, 2011.

[19] J. F. Hair, C. B. William, J. B. Barry, and E. A. Rolph, Multivariate Data Analysis, Englewood Cliffs, NJ: Prentice Hall, 2010.

[20] S. Barr, "Factors influencing environmental attitudes and behaviors: A U.K. case study of household waste management," Environment and Behavior, vol. 39, pp. 435-474, 2007.

[21] Y. Irimiya, I. A. Humphery, and I. I. Aondover, "Assessment of energy use pattern in residential buildings of Kano and Kaduna Northern Nigeria," American Journal of Engineering Research, vol. 2, pp. 271-275, 2013.

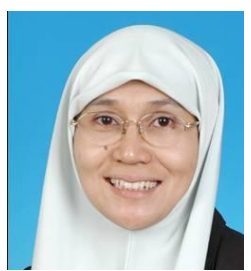

Nor'Aini Yusof is an associate professor at the School of Housing, Building, and Planning in the Universiti Sains Malaysia (USM). She holds a diploma in valuation and a bachelor of surveying (Hon.) in property management from the Universiti Teknologi Malaysia, a M.Sc. in project management and $\mathrm{a} \mathrm{PhD}$ in housing from USM. Her research interests include innovation studies, property development and management, and sustainable practices. She has published in national and international journals and conference proceedings. She is a member of the editorial board for the Journal of Construction in Developing Countries and Emerald Emerging Markets Case Studies. She is also an assistant editor for the International Journal of Organizational Innovation. She regularly reviews technical papers for international and local journals and conferences. She supervises research students both at the $\mathrm{PhD}$ and masters levels.

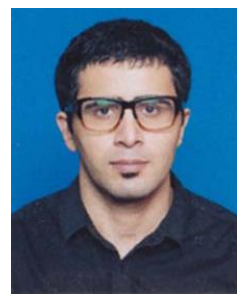

Mohammad Iranmanesh is a doctoral candidate at the School of Management in the USM. He received his MBA from the Graduate School of Business also in the same university.

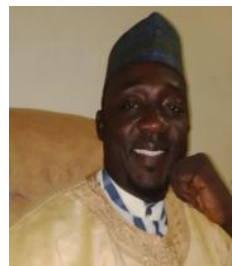

Aminu Garba Waziri is a certified estate surveyor and valuer. He is currently a $\mathrm{PhD}$ candidate in project management and a Graduate Research Officer with the School of Housing, Building, and Planning in the USM. He holds the HND in estate management, the PGD in environmental management, and the M.Sc in housing. He was a supervisory councillor for education and social services and secretary to Malumfashi local government council in Katsina State, Nigeria. He was a member of the Board of Directors of Nigerian Film Corporation, a senior legislative aide in the House of Representatives, a partner at AG WAZIRI \& Co., and a lecturer at the Nuhu Bamalli Polytechnic Zaria, Kaduna State. He has published more than 10 articles and presented at various conferences. His research interests include housing and real estate, built environment, and construction sector sustainability. 